\title{
Rekontruksi Nilai-Nilai Konsep Tritangtu Sunda Sebagai Metode Penciptaan Teater Ke Dalam Bentuk Teater Kontemporer
}

\author{
TATANG RUSMANA \\ Jurusan Teater. Fakultas Seni Pertunjukan, Institut Seni Indonesia Padangpanjang. \\ Jln. Bahder Johan, 35 Kota Padangpanjang 27128 Sumatra Barat - Indonesia \\ E-mail: tatangrmacan@yahoo.com
}

\begin{abstract}
Konsep filosofi Tritangtu Sunda, sebagai falsafah hidup masyarakat Sunda di Kabupaten Bandung. memiliki tiga makna penting tentang pembagian dunia, tiga dunia itu yakni Buana Nyungcung (Dunia Atas, simbolnya; Langit, Air, dan Perempuan), Buana Larang (Dunia Bawah, simbolnya; Bumi, Tanah, dan Laki-laki), dan Buana Pancatengah (Dunia Tengah, simbolnya; Batu, Manusia, Laki-laki dan Perempuan). Tritangtu Sunda merupakan perspektif penyatuan tiga dunia dalam kehidupan masyarakat petani. Penyatuan tersebut yaitu perkawinan Buana Nyungcung dengan Buana Larang, dan Buana Pancatengah-lah yang menyatukannya. Konsep Tritangtu Sunda berpengaruh terhadap seni tutur Wawacan yang lazim ditampilkan ke dalam Seni Beluk. Wawacan inilah yang ikut membentuk pikiran kolektif masyarakat Sunda. Wawacan yang menjadi sumber penelitian disertasi ini adalah "Wawacan Nata Sukma" yang ditulis anonim oleh masyarakat Banjaran, Kabupaten Bandung tahun 1833 M (abad ke-19) dalam masa "tanam paksa" untuk menanam kopi di Pangalengan. Tritangtu Sunda akan difungsikan sebagai perangkat penciptaan seni teater berbasis teater kontemporer (terutama penyutradaraan). Penelitian menggunakan penajaman teori resepsi Isser, untuk mengaktualisasikan karya dengan cara yang berbeda, karena tidak ada tafsir tunggal yang benar (Culler, 2003). Pendekatan lain pendapat George Land dari teori transformasi, diartikan sebagai sebuah kreasi baru atau perubahan ke bentuk yang baru baik secara fungsi maupun strukturnya. "To transform", berarti mengkreasikan yang baru yang belum pernah ada sebelumnya, transformasi juga bisa berarti perubahan "polapikir". Perangkat penelitian menggunakan metoda yang disarankan Schechner (2002 dan 2004) dan metode mise en scene yang dirumuskan oleh Patrice Pavis.
\end{abstract}

Katakunci: tritangtu sunda, wawacan nata sukma, beluk, teater kontemporer.

\section{Reconstruction Values Of The Sunda Tritangtu Concept As A Method Of Creating Theater Into Contemporary Theater}

The concept of the Sunda Tritangtu philosophy, is the life philosophy of the Sundanese community including in Bandung regency. Derived from this philosophy are three important meanings of the division of the world, the three worlds are Buana Nyungcung (Upper world, its symbols: Heavens, Water, and Woman), Buana Larang (Underworld, symbols; Earth, Land and Man), and Buana Pancatengah (Middle world, symbol: Stone, Man, Man and Woman). The Sundanese Tritangtu is the perspective of the unification of the three aforementioned worlds in peasant life. The union is the marriage of Buana Nyungcung with Buana Larang, and Buana Pancatengah is the one that unites it. The concept of the Sundanese Tritangtu influences the art of Wawacan speech that is commonly integrated into the art of Beluk. Wawacan is a contributing factor in what helped shape the collective minds of the Sundanese people. Wawacan, which is the source of this dissertation research, is "Wawacan Nata Sukma", written anonymously by Banjaran society, Regency of Bandung in 1833 AD (19th century) during "Cultuurstelsel" to grow coffee in Pangalengan. Sunda Tritangtu functions as a tool for the creation of theater based contemporary theater modalities (especially directing). This research uses Isser's reception theory, to actualize the work in different ways. There is no single correct interpretation (Culler, 2003). Another approach of George Land's opinion of the theory of transformation, defined as a new creation or change to a new form both in function and structure. "To transform", means creating a new one that has never existed before, transformation can also mean a change of "mindset". The research used Schechner's method (2004 and 2004) and the mise en scene method formulated by Patrice Pavis.

Keywords : tritangtu sunda, wawacan nata sukma, beluk, contemporary theater. 


\section{PENDAHULUAN}

Masyarakat suku Sunda adalah orang Pasundan yang biasa disebut urang gunung, wong gunung, dan tiyang gunung, artinya orang gunung disampaikan oleh ENI, IV, 1921; Rosidi, 1984; 129; Adiwilaga, 1975. Besar kemungkinan timbulnya sebutan tersebut setelah adanya anggapan bahwa pusat tanah Sunda di Priangan. Priangan memang merupakan daerah pegunungan dengan puncak-puncaknya yang cukup tinggi. (via Ekadjati, 2014: 8). Masyarakat Sunda sekarang juga dipertalikan sebagai orang Jawa Barat (istilah Jawa Barat berasal dari orang Belanda dari istilah West Java, muncul pada abad ke-19 Masehi sebagai bentuk penguasaan pemerintahan kolonial Hindia Belanda). (Ekadjati, 2014: 8).

Budaya awal masyarakat Sunda seperti yang tergambarkan pada masyarakat Kanekes, ditandai dengan keyakinan pada agama Sunda Wiwitan. Wiwitan berarti mula pertama, asal, pokok, jati. Dengan kata lain, agama yang dianut orang Kanekes adalah agama Sunda Asli. Menurut Carita Parahiyangan adalah agama Jatisunda (Ekadjati, 2014: 62). Dilanjutkan pada abad ke 4 hingga ke 16 pada masa Hindu, bahwa budaya yang bertahan hingga sekarang dari masyarakat Sunda, adalah masyarakat petani yang hidup dari kebiasaan berladang (huma), berkebun, sebagaian berburu hewan hutan dan ikan dari sungai yang banyak mengalir di antara celah-celah pegunungan dan danau yang terjadi secara alami serta danau buatan. Semula kebiasaan pola hidup tersebut hanya untuk mencukupi kebutuhan hidup sehari-hari tidak untuk dijual belikan.

Dalam penelitian ini, fokus kerja penelitian dipusatkan pada sub-kultur Sunda yakni masyarakat Bandung. Masyarakat Bandung yang dikenal sebagai orang Parahyangan di masa lalu, mereka adalah orang-orang yang tinggal di daerah pegunungan dengan hidup berladang. Sistim berladang seiring perubahan zaman bergeser masuk pada masa pertanian sawah, terutama di Kabupaten Bandung yaitu Bandung wilayah Selatan. Budaya sawah dipahami sebagai pewarisan dari tata cara kegiatan masyarakat kaum ladang yang hidup dalam tatanan pola tiga. Sebagai masyarakat ladang mereka memiliki pandangan tiga dunia penting dalam kehidupan ini. Pandangan tersebut yakni langit pemberi hujan, tanah yang menumbuhkan tanaman, dan manusia yang mengawinkan hal itu dengan cara mengawinkan langit dan bumi.

Inilah sebabnya dikenal tiga buana atau dunia, yakni Buana Nyungcung (atas, langit), Buana Pancatengah (tengah, manusia), dan Buana Larang (bumi). Simbolnya adalah air (atas), tanah (bawah), dan batu (tengah). Sistim hubungan pola tiga dalam budaya Sunda bersumber dari hubungan langit, bumi dan manusia. Ini berarti hubungan air, tanah, dan batu. Hubungan Resi (air), Ratu (batu), Rakyat (tanah). Hubungan perempuan (langit/air), lelaki (bumi/kering), dan perempuan-lelaki (manusia). Hubungan pasif (perempuan), aktif (laki-laki), dan pasif-aktif (perempuan-lelaki). (Sumardjo, 2014: 177).

Penyatuan pola tiga di atas yaitu perkawinan Buana Nyungcung dengan Buana Larang, dan Buana Pancatengah-lah yang menyatukannya. Tanaman padi dapat terus hidup kalau ada "perkawinan" antara Langit dan Bumi. Langit mencurahkan hujannya kepada tanah yang kering. Dengan demikian langit itu "basah" dan bumi itu "kering". Basah itu asas perempuan dan kering asas lelaki. (Sumardjo, 2014: 198). Perspektif tiga dunia dalam penyatuan masyarakat peladang ketika bergeser ke sistim bersawah tetap terpelihara dan jadi pedoman arah hidup yang disebut Tritangtu Sunda. Tritangtu adalah cara berpikir masyarakat tradisional Sunda. Masyarakat tradisional Sunda memaknai tritangtu sebagai falsafah hidup untuk mendapat harmoni dengan alam. Kata tri atau tilu yang artinya tiga dan tangtu yang artinya pasti atau tentu. Tritangtu sebagai falsafah hidup ini berpedoman pada tiga hal yang pasti yakni; Batara Tunggal yang terdiri dari Batara Keresa, Batara Kawasa dan Batara Bima Karana. Dalam budaya kemasyarakatan dan pemerintahan, konsep Telu Tangtu ternyata telah ada sejak zaman Kerajaan Sunda. Dalam koprak 630 disebut adanya tritangtu yang dipandang sebagai peneguh dunia dan dilambangkan dengan raja sebagai sumber wibawa, rama sebagai sumber ucap (yang benar), dan resi sebagai sumber tekad (yang baik). Disampaikan oleh Atja dan Saleh Danasasmita. (via Ekadjati, 2014: 67).

Budaya sawah memiliki makna yang makro tidak saja terbatas pada kegiatan bercocok tanam. Budaya sawah mencakup kegiatan kesenian kaum petani, serta kegiatan religius mereka yang tumbuh untuk mengagungkan dewi kehidupan. Budaya sawah dalam perjalanan waktunya banyak melahirkan proses seni pertunjukan, yang terhubung dengan keyakinan masyarakat petani penganut agama padi (pada masa Hindu hingga abad ke-16) ketika mereka masih berladang (berhuma). Proses seni ini dilanjutkan pada periode bersawah ketika Islam masuk (abad ke-17). Masyarakat petani sangat akrab dengan Seni Beluk ${ }^{l}$, yang merupakan bentuk permainan seni vokal dan terpelihara menyesuaikan dengan ke Islaman para petani di Bandung.

Masyarakat petani di Bandung, adalah masyarakat terbuka dan dinamis pada perkembangan budaya 


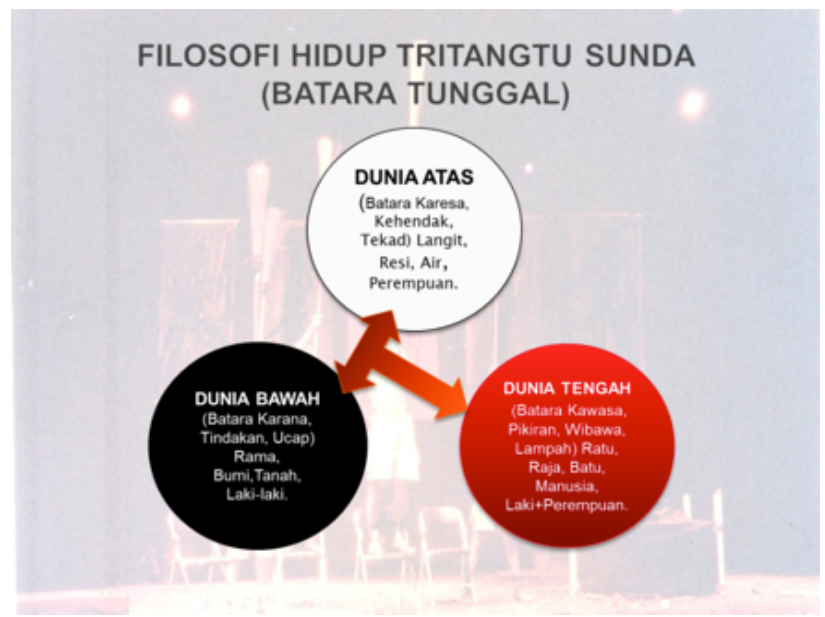

Gambar 1.

Tabel Tritangtu Sunda.

yang datang. Ironisnya, keterbukaan budaya tersebut malah menjadi penyebab penyusutan budaya sawah. Penyusutan ini disebabkan pihak pemerintahan Orde Baru hingga Reformasi sekarang, terlalu terbuka terhadap investor asing pengembang industrialisasi di area perkotaan daerah Bandung telah berubah menjadi kota metropolitan. Pelbagai indikasi perkotaan yang berubah adalah tata ruang dan tata kotanya, pembangunan fisik bangunan (dari perkantoran sampai pertokoan, bahkan perhotelan). Efek sampingnya udara segar tak lagi dapat dinikmati, daerah-daerah pinggiran telah menyimpan polusi dan limbah, pabrik-pabrik dan industri lainnya telah menjadi benteng kota yang tanpa terasa mengepung kita (via Rusmana, 2011: 322).

Perubahan tata ruang memicu rusaknya ekologi, pencemaran lingkungan-hidup dan hadirnya limbah-libah industri serta limbah pusat perbelanjaan. Terjadi pula deforestasi hutan lindung yang tidak terkontrol di Bandung wilayah Utara dan Selatan. Dari tahun ke tahun masalah pencemaran lingkungan hidup di Bandung ini, tidak pernah tuntas diatasi dan kurang diperdulikan oleh pemerintahan dan masyarakat. Masyarakat Bandung sekarang terjebak pada realitas kehidupan kota modern yang serba praktis, konsumtif dan individualis. Namun tidak semua masyarakat meninggalkan tatakrama budaya sawah yang kolektif dan guyub. Meskipun dihadapkan dengan ekologi yang tercemar, di pinggiran Bandung yakni di Kabupaten Bandung wilayah Selatan, budaya sawah masih terpelihara dalam bentuk pembacaan seni tutur wawacan yang disajikan dalam bentuk seni beluk.

Tritangtu sepiritnya berpengaruh pada seni wawacan sebagai seni sastra yang dibacakan dan ditembangkan. Wawacan merupakan gambaran masyarakat seluruh Kabupaten Bandung di lingkungan kaum petani (rakyat) yang religius.

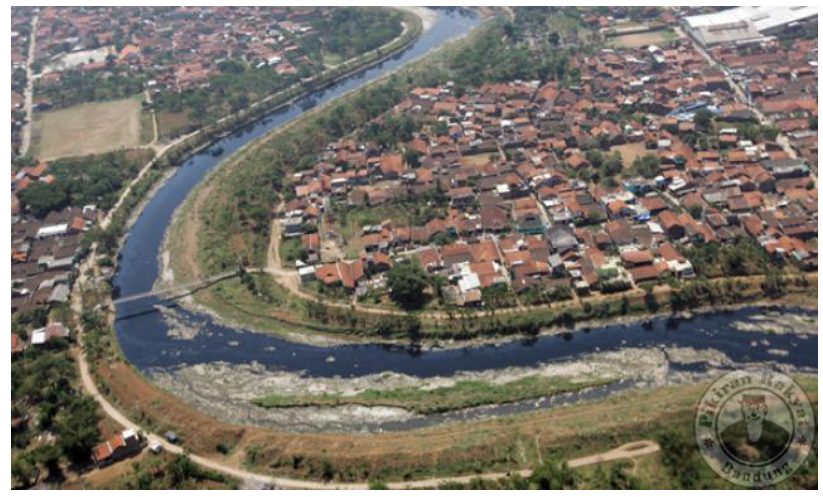

Gambar 2. Kontaminasi Eokologi di Bandung. Di olah dari berbagai sumber 2017.

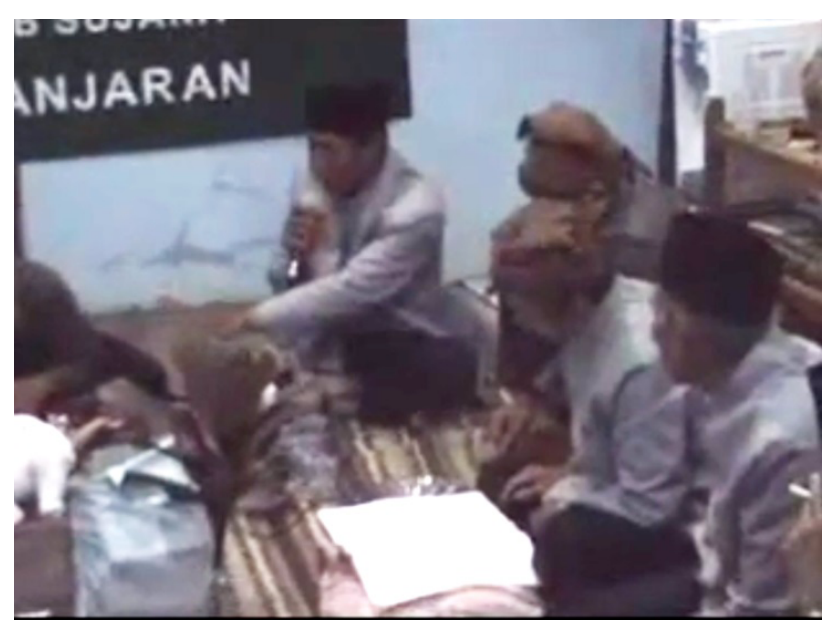

Gambar 3. Seni Beluk Wawacan Pada 40 hari lahiran bayi Diolah dari berbagai sumber di Kabupaten Bandung 2017.

Masyarakat Sunda termasuk di Kabupaten Bandung sejak abad ke-17, setelah memeluk agama Islam dapat disimak dari wawacan-nya. Wawacan inilah yang ikut membentuk pikiran kolektif masyarakat Sunda. Wawacan adalah hikayat yang ditulis dalam bentuk puisi tertentu yang dinamakan dangding. Dangding adalah ikatan puisi yang sudah tertentu untuk melukiskan hal-hal yang sudah tertentu pula

(Rosidi, 1966: 11).

Wawacan yang menjadi bagian penelitian disertasi ini adalah "Wawacan Nata Sukma"2. Wawacan ini ditulis anonim oleh masyarakat sekitar Banjaran, lereng Gunung Cupu Pangalengan, di Kabupaten Bandung."Wawacan Nata Sukma" ditulis dengan huruf Pegon (Arab) dalam bahasa Sunda, sekitar tahun 1833 M (abad ke-19) dalam masa "tanam paksa" untuk menanam kopi di sekitar Pangalengan. "Wawacan Nata Sukma" kemudian ditranskripsi dari huruf Arab ke dalam huruf Latin tahun 1983 oleh Drs. Pepen MEZ. Wawacan ini berupa cerita fiksi tentang 
kehidupan orang pegunungan yang miskin bernama Nata Sukma.

Pelacakan konsep Tritangtu dalam penelitian ini akan digunakan sebagai perangkat penyutradaraan dalam penciptaan teater dengan judul Nata Sukma hasil transformasi dari 'Wawacan Nata Sukma' ke dalam bentuk teater masa kini berbasis teater kontemporer. Konsep Tritangtu Sunda yang berpengaruh ke dalam Beluk dan Wawacan tersebut, penulis rekonstruksi kembali untuk digunakan sebagai perangkat metode penciptaan teater.

\section{LITERATUR DAN PEGEMBANGAN}

\section{PENEITIAN}

\section{Teori Resepsi}

Teori resepsi yang digunakan berpijak pada teori yang mempelajari tanggapan pembaca secara umum terhadap teks itu pada kekiniannya (sinkronik). Teori resepsi ini menekankan pada penelitian terhadap suatu karya kini. Teori ini dikembangkan oleh Isser. Teori resepsi Isser menekankan pada efek, kesan, dari sebuah teks yang dirasakan oleh pembaca secara langsung. Pembaca dengan kemampuan imajinasinya akan langsung melakukan resepsi tehadap sebuah teks dan menghubungkannya dengan realitas yang ada. Rumusan Isser memberikan kebebasan sepenuhnya pada pembaca atas sebuah teks. Ia mengijinkan setiap pembaca melakukan hubungan secara personal dengan teks; pembaca yang berlainan bebas untuk mengaktualisasikan karya dengan cara yang berbeda. Tidak ada tafsir tunggal yang benar (via Culler, 2003: 2-3).

Resepsi sastra dimaksudkan bagaimana "pembaca" memberikan makna terhadap karya sastra yang dibacanya sehingga dapat memberikan reaksi atau tanggapan terhadapnya. Tanggapan sebagai pembaca terhadap sumber materi Wawacan Nata Sukma, yang merupakan bentuk cerita tutur milik masyarakat pertanian di masa 'tanam paksa' untuk menanam kopi di Pangalengan sekitar tahun 1833 M (abad ke-19). Dari uraian alur cerita dan penokohannya, saya melihat hakikat 'estetika perlawanan' terhadap kaum penjajah (Belanda) ketika cerita ini ditulis. Hal ini sangat jelas dari tema yang terkandung di dalam penulisan naskahnya. Tergambarkan dari pergerakan tokoh yang bernama Nata Sukma sebagai anak petani miskin di kawasan pegunungan, yang selalu dihadapkan dalam kondisi perang fisik hingga melepaskan diri dari cengkraman perang. Berpijak dari pembacaan itu, saya melakukan interpretasi yang bersifat aktif, yaitu bagaimana membuat re-kreasi hingga "merealisasikan" mata rantai kreasi-nya ke dalam naskah teater yang baru. Efek dan kesan Wawacan Nata Sukma dengan kandungan moral perlawanan, kaum petani pinggiran Bandung masa lalu itu, saya imajinasikan langsung dan menghubungkannya dengan realitas yang ada dalam kondisi kini secara universal.

Kerja resepsi yang dilakukan telah menghasilkan mata rantai kreasi naskah baru untuk kepentingan penciptaan teater dengan judul Nata Sukma. Kandungan visi perlawanan yang diangkat dalam penciptaan naskah teater Nata Sukma, bukan lagi pada pendekatan penjajahan fisik atau perang fisikal secara langsung. Tetapi menekankan pada perang yang bersifat imajinatif, simbultan terhadap realitas kondisi masa kini, yang dilatar belakangi oleh rusaknya ekologi akibat pertumbuhan modernisasi dan industri kota modern, mengkritisi kebijakan sosial-politik rezim Orde baru hinga Reformasi yang tidak berpihak pada hayat hidup rakyat. Sementara untuk pengkarakteran tokoh utama, masih menggunakan tokoh-tokoh dari latar belakang petani. Dengan demikian, suatu karya akan punya nilai lampau dan makna kini (past significance and present meaning). Adanya fenomena ini memungkinkan kita untuk menciptakan suatu suasana penerimaan tertentu berdasarkan ideologi tertentu (Yunus, 1985: 122-123).

\section{Transformasi Bentuk}

Merujuk pada pendapat George Land tentang transformasi. Teori transformasi adalah deskripsi tentang perubahan struktur dari sebuah sistem yang asli atau natural. Selain itu tranformasi juga bisa diartikan sebagai sebuah kreasi baru atau perubahan ke bentuk yang baru baik secara fungsi maupun strukturnya. "To transform" atau mengubah, berarti mengkreasikan yang baru yang belum pernah ada sebelumnya dan tidak diperkirakan sebelumnya, namun transformasi juga bisa berarti perubahan "pola pikir" (mindset) (Land, 1973: 25). Transformasi terdiri dari beberapa tipe, antara lain transformasi geometri dan transformasi morfologi, dan sebagainya. Transformasi morfologi merupakan proses perubahan bentuk yang berlangsung secara berangsur-angsur sehingga dicapainya tahap paling akhir. Perubahan bentuk ini dilakukan dengan cara memberikan respon terhadap unsur-unsur eksternal dan internal dari bentuk tersebut, melalui teknik penggandaan yang berulang-ulang atau berlipat ganda (multiplicity). Transformasi morfologi terbagi atas tiga klasifikasi; 1). Transformasi dimensional: merubah satu atau lebih dimensinya namun masih mempertahankan bentuk dasarnya, 2). Transformasi substraktif (pengurangan): pengurangan sebagian volume, tetap terlihat bentukan dasar masa tersebut, 3). Transformasi aditif (penambahan): penambahan bentuk dasar masa tertentu dengan bentuk lain, sejenis mau pun yang ber- 
lainan. Bisa juga menjadi kombinasi tertentu (Ching, 2007:5). Pada tahap transformasi ini, penulis mulai dari kerja pemindahan teks Beluk dan Wawacan Nata Sukma sebagai produk tradisi tutur dari masyarakat petani ladang. Proses transformasi telah melahirkan penulisan baru naskah lakon teater, dari bahasa Sunda dengan menggunakan bahasa Indonesia berjudul Nata Sukma. Secara artistik, penulis tidak menghilangkan ciri beluk. Unsur tembang seperti beluk ini, ada pembagiannya yang tetap dipertahankan untuk menghadirkan spirit budaya perladangan atau sawah di tanah Sunda dalam bagian-bagian adegan. Dalam kerja proses penulisan naskah lakon, terjadi dekonstruksi penulisan dari tutur wawacan yang syarat dengan aturan-aturan Pupuh (puisi tertentu berbahasa Sunda) ke dalam naskah lakon teater modern untuk kepentingan penciptaan teater.

Bangunan struktur cerita, dan latar peristiwa terjadi perubahan, sebagian besar tokoh-tokoh yang dihadirkan terjadi perubahan dengan "tokoh gagasan", kecuali tokoh utamanya tetap dipertahankan, demikian juga untuk perkembangan latar suasana dan tempat, perubahan plot dan unsusr-unsur plot. Terjadi juga perubahan unsur diksi yang berkembang hingga ke arah diksi secara visual. Penciptaan teks baru dilalui dari sistim resepsi yang dikembangkan oleh Isser, sementara proses perubahan bentuk teks diolah dari transformasi yang di tawarkan George Land.

\section{Teori mise en scene Patrice Pavis, Theatre at The Crossroads of Culture (1992).}

Dan Pertemuan Budaya Sumber dan Budaya Target, terjemahan Yudiaryani (2015).

Pendekatan lain yang digunakan sebagai jembatan untuk mewujudkan konsep penciptaan, ditempuh dalam beberapa tahapan yang dirumuskan oleh Patrice Pavis via Yudiaryani dalam teori mise en scene (Yudiaryani,2015:31-35). Wilayah pertemuan konteks T sebagai mise en scene atau wilayah pertemuan antara situasi yang dikehendaki pengirim dengan situasi yang dikehendaki penerima. Teks kebudayaan masyarakat peladang dan sawah, di tanah Sunda Kabupaten Bandung sub kultur Sunda. Teks berupa perspektif filosofi kosmik Tritangtu Sunda (tiga pembagian dunia dalam penyatuan), beluk dan teater tutur wawacan Nata Sukma sebagai budaya sumber, dilakukan tranformasi ke dalam suasana sekarang sebagai budaya target (T). Rantai pertemuan budaya sumber dan budaya target $(\mathrm{T})$ dalam proses penciptaan digarap melalui pembentukan mise en scene pertunjukan. Tahapannya berlangsung dalam tahapan sebagai berikut:

Penciptaan digarap melalui pembentukan mise en

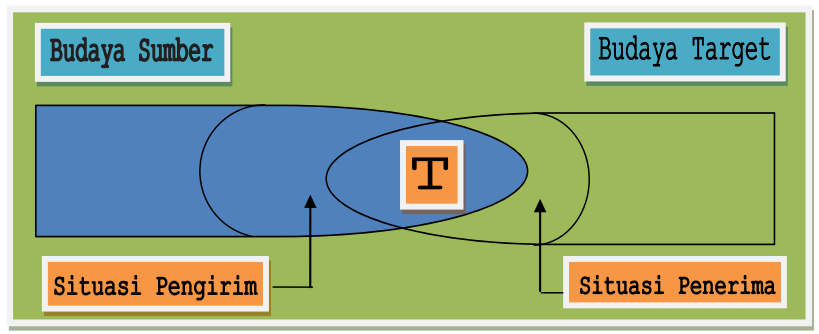

Gambar 4.

Skema Pertemuan Budaya Sumber dan Budaya Target.

scene pertunjukan. Tahapannya berlangsung dalam tahapan sebagai berikut:

Tahap pertama (TO), yaitu menuliskan rancangan cerita lisan atau dongeng-dongeng untuk skesa-sketsa yang akan ditampilkan dan treatment dari wilayah budaya sumber seniman. 'Teater provokasi' yang akan dipentaskan berdasarkan studi pustaka dan perumusan konsepsi masih abstrak. Bahan yang didapat pada proses ini berupa naskah tutur 'wawacan Nata Sukma' sebagai tahapan pertama (TO), yaitu menuliskan rancangan cerita lisan atau dongeng-dongeng cerita fiksi, permasalahan sosial dan lingkungan saat cerita fiksi itu hadir dan pada masa perkembangannya. Materi lainnya adalah perspektif kosmik Tritangtu Sunda, yaitu Buana Nyungcung (Dunia atas/ langit), Buana Larang (Dunia bawah/bumi), dan Buana Pancatengah (Dunia tengah/manusia). Namun demikian, tahapan ini merupakan sumber garapan penciptaan dan sumber budaya yang akan menjadi pesan kepada penerimanya.

Tahap ke dua (T1) yaitu observasi artistik budaya sumber. Tahap ini merupakan langkah pengamatan dan pelacakan data, penulis melakukan wawancara di wilayah budaya Sunda (Kab. Bandung) pada beberapa tokoh Sunda mengenai;

Segala hal yang berkaian dengan beluk, teater tutur wawacan Nata Sukma dan pandangan kosmologi Tritangtu Sunda yang berpengaruh di tanah Sunda.

Kemudian budaya dan karakteristik manusia Sunda, sampai mendapatkan gambaran yang jelas mengenai sosok dan karakteristik permasalahan budaya yang sedang dihadapi oleh lingkungan sosial budaya masyarakatnya.

Tahap ke tiga (T2) merupakan perspektif seniman. Kongkretisasi dramaturgi, berpijak dari beluk dan tutur wawacan Nata Sukma yang telah dilakukan transformasi, menjadi lakon Nata Sukma diolah dengan permasalahan kondisi masa kini. Diwujudkan ke dalam elemen artistik penciptaan teater kontemporer, dengan mengkolaborasikan unsur teater tradisi dan modern serta memasukkan konsep teater lingkungan 


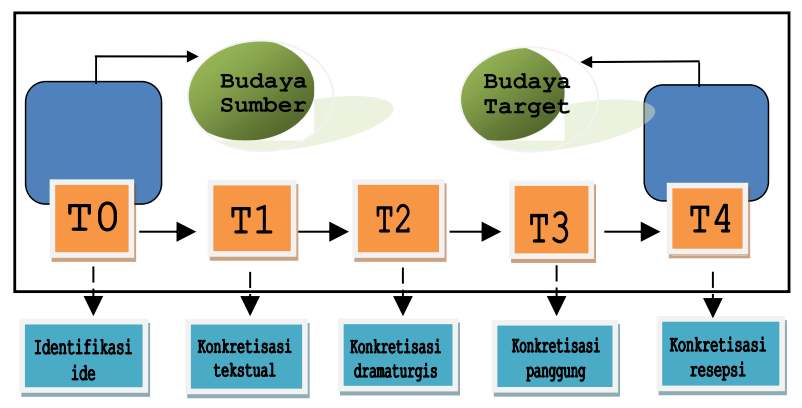

Richard Schechner.

Tahapan keempat (T3), merupakan stage concretization, Tahapan ini penulis berusaha mendekatkan perspektif dengan penerimanya melalui pertunjukan. Cerita atau kondisi sosial masa kini, diwujudkan dalam bentuk pertunjukan 'teater provokasi' melalui pendekatan teater tradisi dengan perkembangan teater modern yang ada. Pemanggungannya akan menggunakan naskah lakon sebagai pedoman uraian verbal, ornamentasi bentuk dalam lapis luar pertunjukan akan disetilir melalui unsur-unsur permainan vokal seperti dalam Beluk, pengembangan gerak-gerak, bunyi-bunyian ataupun segala hal keunikan yang terdapat dalam pertemuan tradisi-modern. Panggung atau ruang pertunjukan dapat ditampilkan di teater proscenium ataupun arena.

Tahapan kelima (T4), merupakan receptive concretization, dimana penulis melakukan uji coba pendekatan konkretisasi penciptaan elemen-elemen pertunjukan dengan penerimanya. Terjadinya pertemuan antara kreativitas model artistik penulis dengan penonton diharapkan mampu meningkatkan kualitas estetis seni pertunjukan teater.

Tahapan kerja model Pavis tersebut, dapat digunakan untuk melakukan proses kerja pembentukan teks baru dari teks sebelumnya. Tahapan ini dapat juga digunakan dalam penciptaan teater untuk membangun kreativitas artitstiknya melalui tahapan teknis T1, T2, dan T3. (via Yudiaryani, 2015: 31-38 dan Pavis, 1992: 137-142).

\section{PENDEKATAN PENELITIAN}

Dominasi penelitian diarahkan pada penelitian lapangan dengan menggunakan metode kualitatif. Fokus penelitian pada asfek performativitas dan naratifitas (filosofi konsep tritangtu Sunda dan Beluk-Wawacan di Kabupaten Bandung). Pada dua aspek ini penggalian data dilakukan untuk melakukan proses pelacakan sumber dan implementasi gagasan yang diajukan. Pendekatan penelitian yang digunakan adalah pendekatan etnogafi dan fenomenologi. Penulis berupaya melakukan pelacakan langsung pada beberapa sumber tokoh masyarakat Sunda di Bandung dan akademisi seni, yang dipandang memahami kedudukan filosofi Tritangtu Sunda dalam fungsinya bagi kehidupan. Upaya yang dilakukan, juga dengan cara membaur secara lebih dekat dengan para pelaku Beluk-Wawacan, untuk menggali berbagai pengalaman, pandangan, dan bagaimana mereka memosisikan serta memaknai Beluk-Wawacan dalam pemaknaan kehidupan pada masa lalu dan sekarang. Penelitian berjalan secara alami dan bersifat dialogis dengan tidak melakukan pengkondisian tempat secara khusus. Instrumen utama penelitian yakni penulis sendiri.

Fokus penelitian yang dilakukan peneliti dengan menggunakan cara-cara pendekatan yang di terapkan Richard Schechner, dalam buku Performace Studies (2002). Menurut Schechner ada empat cara yang harus dilakukan dalam penelitian studi pertunjukan, yaitu: 1). Prilaku adalah "objek studi”, 2). Praktik artistik, 3). Kerja lapangan sebagai partisipan observasi, 4). Terlibat secara aktif dalam praktik-praktik sosial dan advokasi (Schechner, 2002: 1-2). Pendekatan yang dilakukan Schechner, terutama terkait pada wilayah seni pertunjukan yang berkaitan dengan upacara ritual. Ritual menurut Schechner adalah suatu cara agar orang bisa mengingat sesuatu, merupakan memori-memori dalam tindakan yang disandikan ke dalam tindakan atau aksi untuk membantu manusia dalam menghadapi transisi yang sulit, relasi yang bertentangan (ambivalen), berbagai hierarki, dan keinginan-keinginan yang menyulitkan, melampaui atau melewati sesuatu, atau mengganggu norma-norma dalam kehidupan sehari-hari (Schechner, 2002: 45).

Ritual oleh Schechner dibagi menjadi dua jenis yaitu sakral dan sekuler. Ritual sakral yakni ritual yang berkaitan dengan cara mengekspresikan atau melakukan kepercayaan-kepercayaan religius. Dengan asumsi bahwa sistem-sistem kepercayaan religius melibatkan komunikasi melalui doa atau memohon bantuan kepada kekuatan-kekuatan gaib. Sedangkan ritual sekuler adalah ritual-ritual yang berkaitan dengan upacara kebesaran, hidup sehari-hari, dan aktivitas lain yang karakter religiusnya tidak terlalu rinci. Namun, menurut Schechner pembagian ini hanyalah palsu, karena banyak upacara kebesaran yang berkualitas sama dengan suatu ritual religius, dengan memainkan peran seperti transenden dan kekhusukan (Schechner, 2002: 47).

Pengembangan untuk implementasi temuan penelitian, masih menggunakan pendekatan model Schechner dalam buku Performace theory (2004). Ia menjelaskan struktur dasar pertunjukan terdiri atas tiga tahap, yaitu: persiapan, pertunjukan, dan aftermath. Tahap persiapan, yang utama adalah menyiapkan latihan, workshop, dan persiapan pentas. Tahap per- 
tunjukan, adalah peristiwa melakukan pertunjukan, tahap pertunjukan terkait juga dengan penonton. Tahap aftermath, adalah kegiatan yang dilakukan setelah pertunjukan selesai. Schechner menjelaskan juga bahwa ada lima aktivitas yang berkaitan dengan pertunjukan yaitu: play (bermain), permainan, olah raga, teater, dan ritual. Kelima aktivitas itu, oleh Schechner dikelompokan menjadi tiga, yaitu: pertama, play atau bermain, adalah aktivitas bebas, para pelaku atau orang yang terlibat dalam bermain dapat membuat aturan permainan sendiri; kedua, ritual adalah kegiatan yang diprogram secara ketat, aturan dibuat untuk ditaati oleh para pelaku sesuai dengan fungsinya;

ketiga, permainan, olah raga, dan pertunjukan kesenian yang aturannya berada di antara bermain dan ritual. ( Schechner, 2004: xviii).

Bagian terpenting dari pertunjukan (magnitudes performance) yang mencakup narativitas, teatrikalitas, performativitas. Narativitas berkaitan dengan narasi yang diungkapkan dalam pertunjukan, teatrikalitas berkaitan dengan unsur-unsur pertunjukan dan teknik-teknik yang dilakukan oleh para pemain dalam pertunjukan, dan performativitas berkaitan dengan penampilan atau keterampilan dari pertunjukan itu. ( Schechner, 2004: 326).

\section{PEMBAHASAN DAN IMPLEMENTASI}

"Tritangtu Sunda" Adopsi Spirit Sunda Tradisi Pada Masyarakat Petani Ladang dan Sawah di Tanah Sunda,

Filosfi tritangtu Sunda merupakan pewarisan masyarakat suku Sunda di masa lalu, yang tinggal di daerah pegunungan dengan kehidupan primordial kaum peladang. Sistim berladang seiring perubahan zaman kemudian bergeser masuk pada masa pertanian sawah. Kegiatan bersawah dipahami sebagai hasil pewarisan produk lokal, dari tata cara kegiatan masyarakat kaum peladang yang hidup di pegunungan dalam tatanan pola tiga.

Kehidupan pola tiga semula merupakan perspektif tiga dunia kaum peladang yang antagonistik saling bertentangan. Secara kosmologi mereka mengenal tiga pembagian dunia yaitu; Buana Nyungcung (atas, langit), Buana Larang (bawah, tanah), dan Buana Pancatengah (tengah, manusia). Sehingga untuk terjalinnya daya kehidupan yang harmonis perlu adanya penyatuan antara dua dunia yang paradoks (bertentangan) itu. Penyatuan tersebut yaitu perkawinan Buana Nyungcung dengan Buana Larang, dan Buana Pancatengah-lah yang menyatukannya. Dengan tindakan seperti ini akan terbentuk proses kesuburan, pertumbuhan dan kehidupan di muka bumi.

Tanaman padi dapat terus hidup kalau ada "perkawinan" antara Langit dan Bumi. Langit mencurahkan hujannya kepada tanah yang kering. Dengan demikian langit itu "basah" dan bumi "kering". Basah itu asas perempuan dan kering asas lelaki. (Sumardjo, 2014: 198). Langit disebut basah mengandung makna realitas "air", dan Bumi disebut kering mengandung makna realitas "tanah". Selanjutnya perspektif tiga dunia dalam penyatuan masyarakat peladang ketika bergeser ke sistim bersawah tetap terpelihara dan jadi pedoman arah hidup yang disebut Tritangtu Sunda. Tritangtu adalah cara berpikir masyarakat tradisional Sunda. Tritangtu berasal dari bahasa Sunda, di mana kata tri atau tilu artinya tiga dan tangtu artinya pasti atau tentu. Tritangtu itu artinya tiga ketentuan yang pasti. Masyarakat tradisional Sunda memaknai tritangtu sebagai falsafah hidup.

Budaya sawah di tanah Sunda termasuk di Kabupaten Bandung, memiliki makna yang makro tidak saja terbatas pada kegiatan pola bercocok tanam. Budaya sawah mencakup kegiatan kesenian kaum petani, serta kegiatan relijius mereka yang tumbuh untuk mengagungkan dewi kehidupan. Sawah dimaknai sebagai lahan untuk mengelola dan memelihara pertanian sebagai sumber kehidupan. Sawah tatanannya terdiri dari beberapa unsur alami, yakni unsur tanah, unsur air, unsur angin dan unsur api. Unsur-unsur tersebut seperti halnya unsur-unsur jasmaniah yang menyelubungi hidup manusia, di samping unsur rohani. Empat unsur tersebut menyimbolkan badan manusia yang terdiri dari empat zat dalam bahasa Arab yakni adanya narun (unsur api ), hawa'aun (unsur angin), turobun (unsur tanah), dan ma'un (unsur air).

Mengelola sawah analog dengan pendayagunaan ke empat unsur hidup tersebut, yang dilanjutkan pada proses pembibitan, penanaman benih padi serta pemotongan padi besar ketika datang musim panen. Pengelolaan sawah hakikatnya sebagai pelaksanaan proses perkawinan atau penyatuan antara Langit dan Bumi yang paradoks (bertentangan). Perkawinan itu menyatu dengan ruang gerak manusia di muka bumi menjadi daya kehidupan. Di tanah Sunda, masyarakat melihat langit itu simbol dari air, basah (simbol perempuan, kesuburan), dan bumi itu kering (simbol laki-laki, tanah). Sehingga untuk terjadinya kesuburan di mana tanaman padi bisa tumbuh, keberadaan langit dan bumi itu harus dikawinkan guna mencapai harmonisasi. Tritangtunya itu yakni kesatuan antara langit dan bumi, yang membentuk kehidupan, itulah harmonis hurip dalam Dunia Panca Tengah (realitas manusia). Dengan demikian, keadaan dan realitas alam lingkungan disekitarnya masrakat ladang itu kemudian membentuk cara pandang pikirannya. 
Cara berpikir dalam kepercayaan masyarakat ladang, bahwa suatu keberadaan hidup itu awalnya bersifat dualistik. Semua hal yang dualistik tersebut saling bertentangan satu sama lain, saling beroposisi. Oleh karena saling bertentangan, kemungkinan konflik yang berujung kemusnahan bisa terjadi. Sehingga untuk itu, diperlukan medium yang mengharmonisasikan keduanya. Harmoni itu merupakan integrasi antara dua alamat dualistik, sehingga memunculkan "alamat yang ketiga". Dengan demikian, pemikiran dualistik menjelma menjadi pemikiran tritunggal masyarakat petani di tanah Sunda. Namun secara umum dapat terjadi pada beberapa etnis pegunungan di Nusantara yang berakar pada kehidupan pola tiga, seperti di Sulawesi Selatan dengan konsep "to manurung", di masyarakat Minang Kabau dengan konsep "tigo tungku sajarangan", dan pada masyarakat Medan dengan konsep "dalihan na tolu". Konsep pola tiga adalah umum dimiliki oleh genesis masyarakat pertanian Nusantara.

Tritangtu yang masih konteks dalam masyarakat Sunda saat ini, lazim kita mendengar ungkapan silih asih, silih asah, silih asuh. Menurut Sumardjo, umumnya pemahaman tritangtu modern ini berlaku untuk aspek kesatuannya, dan bukan pembedaannya. Semua manusia Sunda harus saling asih, saling asah, dan saling asuh. Setiap orang harus memiliki sikap tritangtu ini, supaya hidup di tanah Sunda ini menjadi aman, damai, dan sejahtera. Silih asih, silih asah, dan silih asuh ini sama halnya dengan tekad, ucap, lampah yang ada dalam diri manusia. Tekad, ucap, lampah sendiri ada dalam Upanishad yang diucapkan oleh guru bijaksana Yajnavalkya; seseorang memutuskan sesuatu berdasarkan keinginannya, bertindak berdasarkan keputusannya itu, dan berubah menjadi sesuatu berdasarkan tindakannya itu. Pada awalnya yang muncul adalah kehendak, keresa. Kehendak ini nantinya akan menuntut suatu tindakan. Untuk sampai pada tahap tindakan, diperlukan suatu tahap lagi, yaitu pikiran. Dalam hal ini, pikiran merupakan jembatan penghubung antara kehendak dan tindakan. Dalam tahapan ini, suatu kehendak akan diproses untuk mencari jalan bagaimana bentuk perwujudannya dalam perbuatan.

Kehendak, pikiran, tindakan sama dengan tekad, ucap, lampah. Pemaknaan tekad sebagai keinginan, niat, hati nurani, atau cita-cita yang muncul dari kedalaman hati nurani manusia. Kontradiksi tekad adalah lampah, perbuatan, kekuatan, tenaga. Antara keinginan dan pelaksanaan keinginan itu dihubungkan oleh pikiran yang menghasilkan keputusan. Menurut Sumardjo, tritangtu itu ada apabila manusia memutuskan sesuatu berdasarkan keinginannya dan melaksanakan keputusan itu dalam perbuatan atau lampah. Perbuatan atau lampah itulah yang mengu- bah manusia. Dengan demikian, perubahan dalam asas tritangtu adalah bersatu padunya antara tekad, ucap, dan lampah.

Konsep tritangtu ini diungkapan juga oleh Ekadjati (2009:138) sistem pemerintahan kerajaan Sunda pada masa lalu juga didasarkan pada konsep tiga ini yang disebut Tri Tangtu di Bwana atau Tri Tangtu di Bumi (Tiga Unsur Penentu Kehidupan di Dunia). Menurut konsep ini, ada tiga unsur yang menjadi penentu kehidupan manusia di dunia, adalah prebu, rama, dan resi. Tiap-tiap unsur memiliki fungsi dan tugas masing-masing, tetapi secara keseluruhan merupakan kesatuan yang bulat yang mencakup seluruh aspek kehidupan negara dan manusia. Pandangan tritangtu sebagai jati diri manusi Sunda ini disampaikan juga, Hendayana (2003) menyebutkan adanya tiga aspek yang dapat dijadikan tolok ukur terhadap jati diri orang Sunda. Ketiga aspek tersebut adalah pola pikir, pola sikap, dan pola tindak. Hendayana (2005) menyebutkan bahwa indikasi apakah orang (Sunda) masih berjati diri Sunda atau tidak bisa dilihat dari penerapan ketiga aspek tersebut dalam kehidupan kesehariannya.

\section{Implementasi Tritangtu Sunda,}

Dalam masyarakat Sunda, tritangtu diterapkan dalam sejumlah hal, antara lain:

Senjata kujang, yang mempunyai tiga fungsi sekaligus yakni; pukul, potong, dan tusuk

Kampung Sunda, yakni; pemilik, pelaksana, dan penjaga.

Rumah adat Sunda yang terdiri dari; ruang tengah, ruang belakang, dan ruang depan.

Boboko atau wadah nasi yang dibuat dari jalinan bambu yang memilki tiga bentuk yakni bundar, segi delapan, dan bujur sangkar.

\section{Pemikiran Tritangtu Sunda,}

Tritangtu juga diterapkan dalam pemikiran masyarakat tradisional Sunda, antara lain:

Silih asah, silih asuh, silih asih

Tekad, ucap, lampah

Naluri, nurani, nalar

Leuweung larangan, leuweung tutupan, dan leuweung garapan. 
Dunia atas, dunia bawah, dan dunia tengah

Langit pemberi hujan, tanah yang menumbuhkan tanaman dan manusia yang memungkinkan itu, dengan mengawinkan langit dan bumi.

Kembali pada pemahaman budaya petanian di tanah Sunda, termasuk di Kabupaten Bandung yang banyak melahirkan proses seni pertunjukan. Salah satu bentuk kesenian yang lahir dari tata cara pertanian masyarakat Sunda seperti telah disampaikan di awal adalah seni Beluk dan pembacaan seni tutur Wawacan. Prosesi seni ini terhubung dengan tata cara keyakinan masyarakat petani, dengan pandangan filosofi kosmik tritangtu orang Sunda untuk menghormati dewi padi (pada masa Hindu hingga abad ke-16) ketika mereka masih berladang (berhuma). Proses seni ini dilanjutkan pada periode bersawah ketika Islam masuk (abad ke-17), dan menjadi agama anutan yang imanen pada masyarakat petani. Seni Beluk yang merupakan bentuk permainan lengkingan-lengkingan vokal masyarakat petani tetap terpelihara, menyesuaikan dengan ke Islaman para petani di Bandung. Seni Beluk tetap ditembangkan selama ada lahan pertanian sawah, dan ada Tukang Munding ${ }^{3}$ yang melakukan kerja ngawuluku dan ngagaru di antara petakan sawah. Beluk sebagai kesenian rakyat, tetap tertanam ketika masyarakat masih guyub melakukan kegiatan tani.

Seperti telah disampaikan di awal tulisan ini, sejak pemerintahan Orde Baru hingga Reformasi yang terlalu terbuka terhadap investor asing pengembang industrialisasi di area pertanian produktif. Pengaruh industrialisasi makin jelas terlihat pada perubahan dan pengembangan tata ruang permukiman, ruang pertanian produktif, dan ruang hutan lindung area serapan air. Bandung dewasa ini berubah menjadi tata ruang kota modern, diikuti hadirnya pusat-pusat perbelanjaan modern (mall, swalayan, dan super market berbagai nama). pasar induk dan pasar tradisional yang tetap hidup, show room-show room besar kendaraan bermotor merk negara luar, dan hadirnya pabrikpabrik dalam skala besar, yang secara sadar telah mengubah sebagian pola pikir masyarakat dari masyarakat agraris ke masyarakat industri.

Perubahan tata ruang memicu rusaknya ekologi, pencemaran lingkungan-hidup, dengan limbah-libah industri, limbah pusat perbelanjaan dan limbah yang lainnya. Terjadi pula deforestasi hutan lindung yang tidak terkontrol di Bandung wilayah Utara dan Selatan. Masalah pencemaran lingkungan hidup di Bandung, tidak pernah tuntas diatasi dan kurang diperdu- likan oleh pemerintahan dan masyarakat. Perubahan tata ruang telah membuat sebagian masyarakat kurang produktif, pelaku produksi (pertanian) termasuk buruh tani, berpindah profesi menjadi buruh-buruh (pabrik) yang tidak diikuti dengan keterampilan teknis.

Namun tidak semua masyarakat Bandung meninggalkan sepenuhnya tatakrama budaya sawah yang kolektif dan guyub. Meskipun dihadapkan dengan kondisi ekologi yang tercemar, di pinggiran Bandung yakni di Kabupaten Bandung wilayah Selatan, sampai sekarang budaya sawah masih terpelihara dalam bentuk pembacaan seni tutur wawacan yang disajikan dalam bentuk beluk. Pembacaan wawacan ini biasanya dikaitkan dengan tujuan hajatan untuk mendapat keberkahan dan keselamatan. Pewarisan Tritangtu sepiritnya berpengaruh pada seni wawacan sebagai seni sastra yang dibacakan dan ditembangkan. Wawacan banyak berkembang pada masyarakat petani di Kabupaten Bandung. Wawacan merupakan gambaran masyarakat seluruh Kabupaten Bandung di lingkungan kaum petani (rakyat) yang relijius. Masyarakat Sunda termasuk di Kabupaten Bandung sejak abad ke-17, setelah memeluk agama Islam dapat disimak dari wawacan-nya. Wawacan inilah yang ikut membentuk pikiran kolektif masyarakat Sunda dalam hubungannya dengan agama Islam. Kebudayaan Sunda dalam arti sistim nilai, merupakan cerminan dunia batin orang Sunda yang mengakar di masa lampau dan diwariskan dalam tradisi yang hidup sampai hari ini. Tradisi naskah yang terus hidup di masyarakat Sunda adalah tradisi huruf dan bahasa Sunda (baru), yang mulai muncul dalam abad ke 17-18 yang berhuruf Pegon (Arab). Periode ini muncul bersama dengan aktivitas pengislaman Sunda, ditandai dengan sebagian besar naskah rakyat yang berhuruf Pegon dan bahasa Sunda (baru) seperti disampaikan Ajip Rosidi dalam bukunya $\mathrm{Nga}$ langlang Kasusastran Sunda menjelaskan; dalam feodalisme kaum bangsawan dan kaum ulama itu saling mempengaruhi, saling sokong, dan saling bantu hidup bersama. Kalau kaum feodal priayi/menak memegang kekuasaan pemerintahan, kaum ulama memegang superioritas spiritual. Keduanya secara intensif mengamalkan sistim yang didasarkan pada falsafah "guru, ratu, kedua orang tua" (via Sumardjo, 2015: 123).

Inilah sebabnya, dalam banyak wawacan yang muncul pada masa abad ke-17 dan 18 itu, banyak anakanak rakyat dikirim orang tua mereka untuk berguru di pesantren. Azas tritangtu tetap hidup dalam masyarakat dengan filsafat guru, ratu, dan kedua orang tua, atau dalam bahasa modern, ulama, bupati, dan kedua orang tua. Tidak heran apabila naskah rakyat ini banyak ditulis dalam huruf Pegon dalam tradisi 


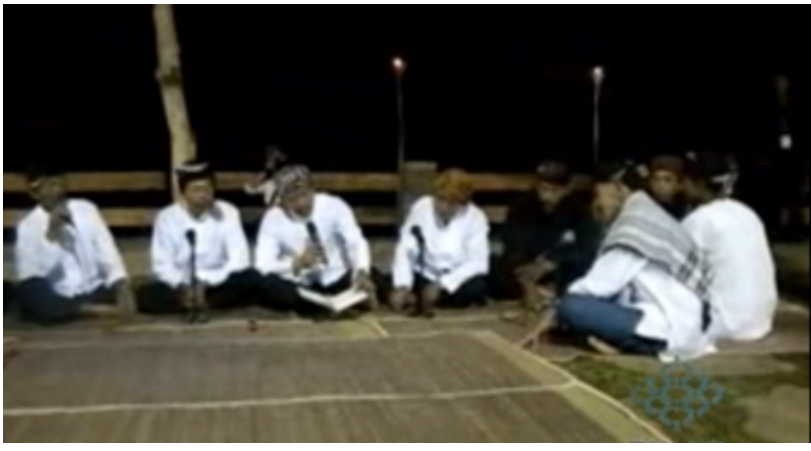

Gambar 5.

Pentas Wawacan disajikan dengan ornamentasi Beluk Diolah dari berbagai sumber, 2013.

"ulama" di pesantren. Filsafat guru, ratu, dan kedua orang tua, ini cocok dan menghunjam dalam unsur sinkronik budaya Sunda sendiri. Azas tripartit tentang pembagian tiga dunia sebagai satu kesatuan yang sudah tua usianya itu dalam masyarakat huma . Azas tangtu tilu atau tritangtu Sunda di buana yang terdiri dari keresian, karatuan, dan keramaan (resi, ratu, rama) adalah akar dari guru, ratu, dan kedua orang tua. Wawacan lazim disajikan ke dalam beluk. Seni beluk ini telah menjadi ornamentasi dan mediasi yang tak bisa dipisahkan dari pertunjukan wawacan itu sendiri. Seorang pemain beluk harus kuat dalam memainkan suara keras panjang. Pertunjukan Beluk dilakukan oleh 4 orang atau lebih, satu orang bertugas sebagai pembaca kalimat-kalimat dari wawacan, kemudian juru $\mathrm{Ilo}^{6}$ yang menyanyikan dari bacaan tersebut dengan lagu pupuh satu persatu (kinanti, sinom, asmarandana, dan dangdanggula). Wawacan merupakan teater tutur dengan menggunakan unsur cerita yang dibaca dan ditembangkan. Pemain menggunakan kostum sederhana, memakai baju kampret atau takwa, sarung atau celana panjang, kopeah atau iket, karena cerita wawacan panjang biasa pemain membawa naskah wawacan. Pertunjukan yang menarik adalah dari permainan beluk, ketika bacaannya yang selalu diulang juru ilo dengan ditembangkan ke dalam suara yang keras dan panjang.

Pembaca wawacan bukanlah penyanyi, melainkan seorang juru baca yang biasa disebut tukang atau juru-ilo yang membacakan baris-perbaris (padalisan) tanpa melagukannya. Baris-baris itulah yang "disambar" (disebut dibeli) oleh penyanyi beluk, dengan lantunan melodi yang sesuai dengan pupuhnya. Juru ilo dan juru beluk bergantian membaca dan menyanyi tiap baris. Akan tetapi, si penyanyi sering tidak menunggu bait selesai dibacakan, ia menyambarnya pada tengah bait, mungkin karena ia merasa telah hafal, atau karena ia akan bisa mendengar setengahnya lagi sambil menyanyi. Oleh karena itu, biasa terjadi

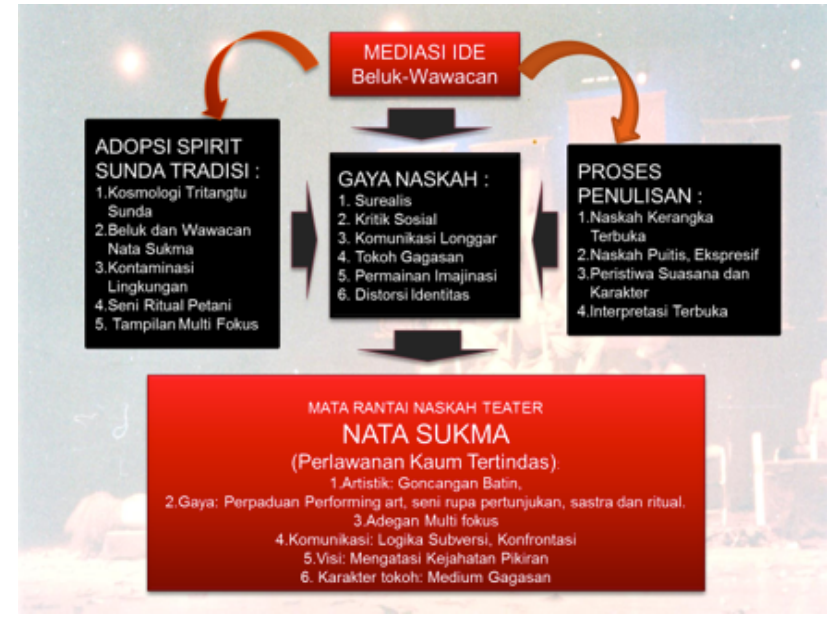

Gambar 6. Tabel Penulisan Teks Naskah Teater Nata Sukma

kesalahan interpretasi. Ketika kesalahan itu terjadi, tidaklah menjadi penilaian pendengar bahwa ia penyanyi beluk yang jelek. Bahkan, hal itu bisa menciptakan keceriaan tersendiri yang membuat pendengar tertawa-tawa.

\section{Implementasi Konsep Tritangtu Sunda (sebagai metode) Dalam Penciptaan Teater (penyutrada- raan dan desain artistik),}

Penerapan konsep Tritangtu Sunda sebagai hasil yang dicapai dapat diuraikan dalam beberapa tahapan temuan, hasilnya berupa; pedekatan model penyutradaraan, konsep desain artistik, konsep struktur penulisan naskah teater, dan perwujudan akting visual keaktoran. Konsep filosofi Tritangtu Sunda, diposisikan dan difungsikan sebagai perangkat pendekatan metode penyutradaraan, untuk penciptaan seni teater masa kini berbasis teater kontemporer. Arsipatoris budaya sumber sebagai materi literature untuk penunjang gagasan penciptaan, yang dimulai dari kerja pemindahan teks lisan Beluk dan tutur wawacan Nata Sukama menjadi naskah teater dengan judul Nata Sukma yang peniliti tulis secara langsung.

Hasil penelitian yang berkembang dari konsep tritangtu Sunda terhadap pembentukkan rancangan ke aktoran, dan rancangan teknik penataan model artistik yang melingkupi desain-desain pemanggungan dapat diurai sebagai berikut;

Dunia Atas atau yang disebut Buana Nyungcung (atas), ruang ini cenderung menunjukan dunia metafisik, tempatnya: Tuhan, Roh, Dewa. Pada ruang ini dalam pandangan kosmologi Sunda di maknai sebagai tempat: Penciptaan, Asal-usul, Kasih, Kejahatan, dan Godaan. Sementara pendekatan laku peran atau akting/visual dapat meliputi: Tubuh Kosmik, Trance, dan Sakral. 
Dunia Tengah atau yang disebut Buana Pancatengah (tengah), ruang ini cenderung menempatkan dunia halus, posisi keberadaan: Raja, Pemimpin, Ksatria. Pada bagian ruang ini, persoalan yang dibangun cenderung pada soal-soal normatif: Kekuasaan, Ambisi, dan Sikap pemimpin. Tata pemeranan yang harus dibangun aktor mengesankan akting/visual: Stilisasi, Terukur Indah, dan Matang.

Dunia Bawah atau yang disebut Buana Larang (bawah), pada bagian ruang ini menempatkan tatanan dunia kasar, bagian posisi: Orang-orang Biasa, Rakyat, Siluman, Demon . Masalah yang dibangun cenderung pada soal-soal keseharian menunjukkan: Rasa Senang, Susah, Sakit, Humor, percobaan. Ruang akting dan visual yang harus dibangun aktor menunjukan: Fisikal, Distorsi, Stilisasi, Mentah, dan Bebas.

Desain yang tertuang dalam gambar di bawah ini melingkupi pembagian ruang pada pola lantai atau ploorplan pemanggungan penciptaan teater yang peneliti sebut sebagai 'teater provokasi'. Pembagian ruang panggung diurai sebagai berikut : Buana Nyungcung (Dunia Atas) berada pada Up Stage, Buana Larang (Dunia Bawah) berada pada Down Stage, dan Buana Pancatengah (Dunia Tengah) berada pada Center Stage. Pembagian ploorplan untuk panggung proscenium dapat dilihat seperti gambar tabel di bawah.

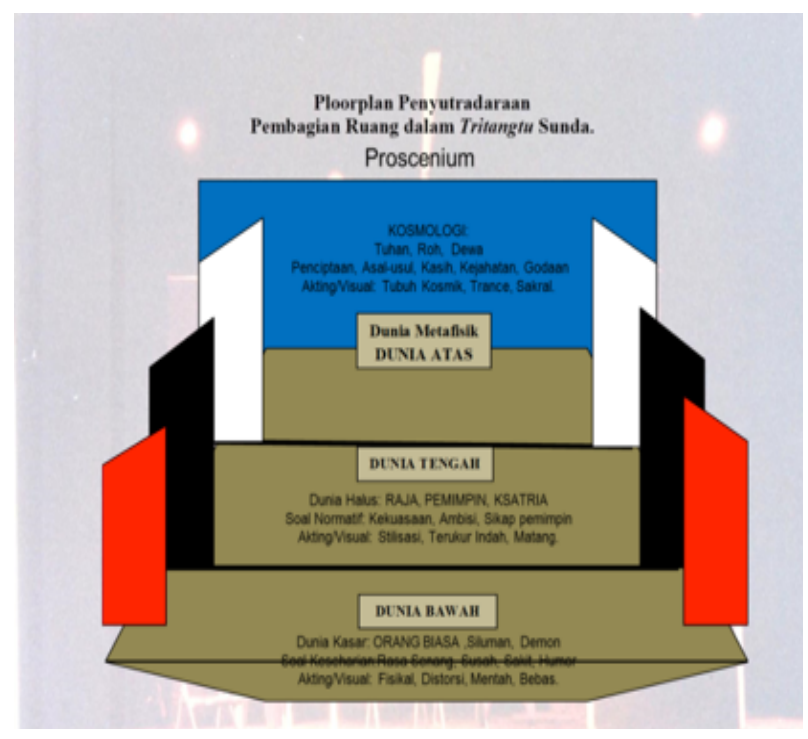

Gambar 7. Tabel Ploorplan Desain Panggung Proscenium.

Selanjutnya denah pembagian ruang dari hasil penelitian konsep filosofi tritangtu Sunda, dapat juga dipetakan untuk desain ploorplan panggung arena tapal kuda. Pada pembagian ruang panggung Are- na Tapal Kuda, ruang mulai menunjukan ke arah persepektif muti fokus. Di mana pandangan audience dapat terbagi dari tiga arah sudut pandang, dengan perspektif panggung memungkinkan untuk terjadi transaksi saling terkait antar tontonan dengan penonton, antara aktor dan apresiator, antara pertunjukan dan masyarakat. Sangat memungkinkan untuk terjadi transaksi saling terkait antara aktor, penonton dan masyarakat ataupun sebaliknya. Pembagian ruangnya seperti tergambar pada uraian berikut (Gambar 8 ).

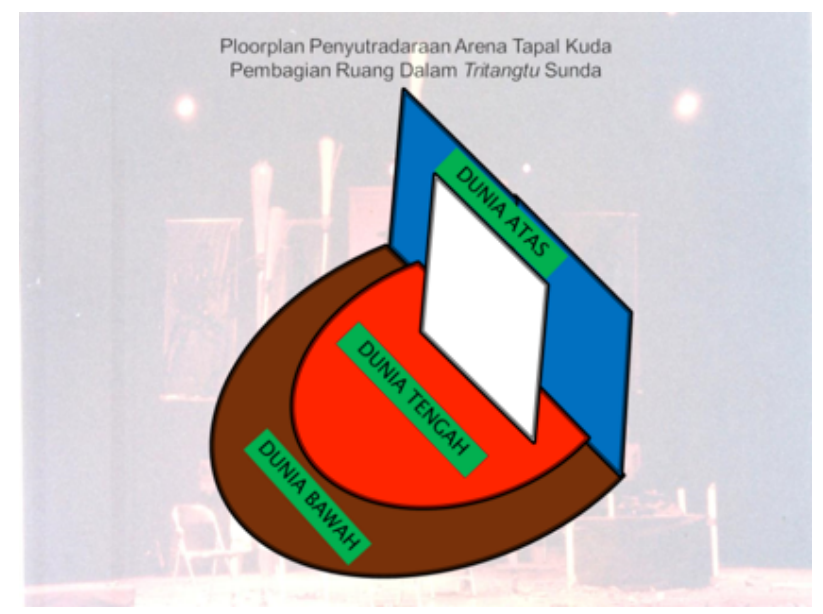

Gambar 8.

Tabel Ploorplan Desain Panggung Arena Tapal Kuda.

\section{Implementasi Konsep Tritangtu Sunda (sebagai metode) Dalam Pengembangan Aktor,}

Teater adalah seni tampilan, sehingga kehadiran manusia menjadi media langsung yang menghidupkan keberadaannya. Ini yang membedakan teater dengan seni lainnya. Manusia dalam seni teater hadir sebagai medium, memiliki fungsi yang komplek untuk terbentuknya penciptaan teater. Itulah sebabnya teater cenderung dipandang sebagai salah satu cabang seni yang bersifat kolektif. Brockett menyebutkan "no approach has greater potential than theatre, since humanity is its subject and human beings is its primary medium" (Brockett,1988: 16). Tidak ada pendekatan yang memiliki potensi lebih besar dari teater, karena manusia merupakan pokok bahasannya dan manusia adalah media utamanya. Ungkapan tersebut lazim terjadi pada perkembangan teater modern, baik yang terjadi di Barat ataupun pada teater Indonesia masa kini. Teater pada intinya terletak pada pertemuan antara manusia dan manusia. Medium teater sebenarnya ada pada aktor yang dalam hal ini manusianya, "...media dalam seni peran adalah diri si pemeran itu sendiri. Pada tubuh pemeran seperti juga manusia lainnya adalah tubuh dan sukmanya" (Anirun, 2002: 61). 
Persiapan tubuh dan sukma para pemain dalam penciptaan teater ini, dilalui dengan serangkaian latihan yang berkaitan dengan penciptaan naskah lakon teater Nata Sukma. Latihan-latihan yang dimaksud berupa observasi dan eksplorasi lingkungan, yang diterapkan kepada para pemain dalam hal Mengenal tubuh lingkungan. Para pemain penulis kenalkan pada pengenalan 'tubuh desa' yang masih alami, belum terkontaminasi dengan pengaruh modernisme. Proses pengenalan ini sekaligus dihadapkan dengan kondisi 'kontaminasi lingkungan', sebagai dampak dari pengaruh budaya industrialisasi.

Observasi dan ekplorasi sistim latihan, dilalui dengan serangkaian pengamatan pada prilaku kehidupan budaya tani, melatih ingatan emosi pemain terhadap ingatan masa lalu tempat kelahirannya, melalui pemahaman literasi lewat arsip-arsip audio-visual seni pertunjukan masyarakat pertanian Sunda. Bahkan dilakukan juga serangkaian pendekatan gejala-gejala prilaku psikologi tubuh dari kecenderungan masyarakat urban perkotaaan akibat modernisme dan industrialisasi.

Pengamatan para pemain terhadap 'tubuh desa' dan 'kontaminasi lingkungan', termasuk pengamatan kondisi prilaku masyarakat pertanian ketika berhadapan dengan cara mereka mengolah ladang ataupun sawah. Cara mereka melakukan interaksi sosial ketika berlangsungnya proses berladang dan sawah, serta prilaku relijius ketika mereka melakukan upacara-upacara pertanian. Sementara 'kontaminasi lingkungan', lebih menekankan pada kecenderungan sosial-psikologis prilaku manusia-manusia yang hidup dalam tatanan modernism. Dari pengamatan tersebut, kemudian diserap dan ditransformasi pada sistim latihan keaktoran untuk mempertajam kepekaan tubuh aktor. Sehingga aktor ketika membawakan peranannya dalam penciptaan teater Nata Sukma, akan lebih mampu menggunakan talenta tubuh dan sukmanya, yang telah terisi dengan upaya pendekatan emosi sosial baik secara fisik maupun psikologis masyarakat petani dan kontaminasi.

Implementasi Tritangtu Sunda yang tertanam pada seni Beluk, ini mampu diterapkan ke dalam sistim latihan olah vokal untuk keaktoran. Pelatihan aktor secara teknis bisa menggunakan cara pelantunan hurup-hurup hidup yang terungkap dari warna vokal yang digunakan dalam teriakan-teriakan atau lengkingan Beluk. Hurup hidup dalam Beluk, cenderung dominasi pada tiga hurup hidup yakni; "(a-A)", "(eE)", "(i-I)” dan "(e'-E')”. Lantunan permainan vokal dengan irama bebas dalam Beluk, sangat memungkinkan untuk eksplorasi pelatihan vocal aktor. Beluk menggunakan juga sistem pernafasan Diafrahma, dengan beberapa penekanan pada vokal tenggorokan dan Head Voice untuk suara-suara yang membutuhkan lengkingan yang tinggi.

Sebagai sebuah gagasan, penciptaan merupakan hibriditas unsur seni yang dimiliki teater rakyat Jawa Barat, dengan perkembangan teater modern ke kinian di Indonesia. Hibriditas unsur-unsur seni tersebut, penulis mengolahnya ke dalam komposisi antara varian seni Beluk, Tarawangsa, Angklung, dan Wayang Golek, yang diolah ke dalam pembauran dengan seni visual multimedia masa kini. Dari unsur yang dimilikinya, dilakukan kolaborasi untuk melihat sisi persamaan dan keunikan. Pada tahapan ini dilakukan seleksi material dan non material, yang memiliki kemungkinan untuk dilakukan rekayasa, distorsi, dan stilisasi guna menemukan kekuatan teatrikalitas yang mampu memberi peluang penciptaan bentuk 'teater baru'.

Dalam pemilahan material terutama difokuskan pada usaha menemukan model artistik, dengan berpijak pada filosofi tritangtu Sunda guna penciptaan teater yang penulis ciptakan. Perwujudan penciptaan, berhasrat melakukan gabungan antara performing arts, seni rupa pertunjukan, sastra, dan ritual. Hasrat Penciptaan terfokus pada tegangan mimpi-mimpi manusia kelas bawah yang mengalami tingkat pemiskinan dan termaginalisasi dari kehidupan. Mereka mendapat benturan dengan sosio budayanya, lingkungan, dengan dirinya sendiri, untuk merebut hidup, untuk 'menemukan hakikat hidup, dan jati diri dalam kehidupan'.

Konsep kerja penciptaan terfokus pada proses penyutradaraan, dilalui dengan tahapan peristiwa yang dialami tokoh, perjalanan tokoh berhadapan dengan dilema moral pada situasi Buana Pancatengah (Dunia tengah/manusia). Pada tahap ini tokoh dihadapkan dengan goncangan pikiran dan goncangan bathin, perasaan nasibnya yang marginal dan tersingkir, kehancuran diri dari konteks sosialnya. Tokoh kemudian melakukan pergerakan horizontal untuk menemukan Buana Nyungcung (Dunia atas/langit). Pada tahap ini tokoh dihadapkan dengan rongrongan dan gangguan dari kekuatan Buana Nyungcung (Dunia atas), sebagai suatu godaan, serta kejahatan yang menggocang bathin dan pikiran. Gangguan atau chaos tokoh (Dunia tengah/manusia) yang berhadapan dengan serangan Dunia bawah, termasuk kegelapan nafsu manusia, memaksa situasi peristiwa si tokoh untuk menemukan realitas Buana Nyungcung (Dunia atas) yang sebenarnya. Realitas tokoh menemukan sublime dirinya setelah menemukan Buana Nyungcung. Pada tahap perjalanan vertikal tokoh meminta dan mengundang bantuan Langit, agar ' $\mathrm{Ca}$ haya Langit' mengiringinya di Buana Pancatengah (tengah/manusia) melawan kejahatan pikiran yang 
ditimbulkan 'nafsu manusia kekuasaan' sebagai realitas Buana Larang (Dunia bawah). Inilah yang penulis maksudkan dengan penciptaan 'teater provokasi' sekarang.

\section{SIMPULAN.}

Konsep filosofi Tritangtu Sunda, adalah falsafah hidup milik masyarakat pola tiga yang hidup berladang di jajaran barisan pegunungan di tanah Sunda/Pasundan. Falsafah ini diyakini sebagai pedoman hidup pada masyarakat Pasundan termasuk di Kabupaten Bandung dan Bandung secara umum. Meskipun dalam perkembangan manusianya mengenal cara bersawah hingga hari ini, namun mereka tidak serta merta meninggalkan pedoman hidup Tritangtu tersebut. Pewarisan konsep filosofi tritangtu Sunda, baik yang diyakini dan dilakukan masyarakat gunung ataupun sawah, banyak melahirkan prosesi-prosesi seni pertunjukan ritual yang khas milik petani yang relijius pada masyarakat Pasundan/Sunda secara umum. Demikian hal-nya dengan yang terjadi pada masyarakat Bandung sub-cultur Sunda, mereka juga memiliki seni pertunjukan yang khas seperti Beluk-Wawacan yang berpedoman pada konsep Tritangtu Sunda. Keberadaan Beluk-Wawacan hingga kini, merupakan identitas seni prtunjukan milik petani baik yang hidup di ladang ataupun sawah di tanah Sunda.

Konsep filosofi tritangtu Sunda dalam penelitian ini, penulis fungsikan sebagai perangkat model pendekatan untuk penciptaan teater, terutama dalam merancang desain-desain penyutradaraan, keaktoran, desain-desain artistik, dan sekaligus pembuatan konsep naskah teaternya. Penciptaan naskah teater dilakukan dengan adopsi seni tutur Wawacan Nata Sukma, yang kemudian penulis pindahkan wujud teks-nya menjadi naskah teater dengan judul Nata Sukma. Proses pemindahan teks, berpijak pada pendekatan resepsi, transformasi, dan adaptasi. Di mana teks di tafsir kearah bentuk penulisan yang lebih merdeka, disesuaikan dengan kondisi kontaminasi lingkungan akibat hadirnya industri dalam skala besar dilingkungan masyarakat Kabupaten Bandung dan Bandung secara luas.

Pokok masalah penelitian ini sebenarnya dalam rangka mengangakat kembali nilai-nilai filosofi Tritangtu Sunda, untuk difungsikan sebagai perangkat model metode penciptaan teater kontemporer. Sehingga kerja penelitian disertasi yang sekarang dilaksanakan, lebih terfokus pada pelacakan, pengamatan, dan arsipatoris material data-data seni milik petani terutama Beluk dan wawacan dalam rangka pembentukan metode penciptaan teater. Proses kerja ini diimbangi dengan beberapa pendekatan teoritis sumber pustaka penunjang, baik yang bersifat literature ataupun au- dio visual, dan photo-photo dari karya-karya seniman terdahulu yang pernah melakukan penciptaan dengan pendekatan spirit budaya tani, pengembangan ritus tradisional dan kontaminasi lingkungan yang dituangkan ke dalam bentuk pertunjukan teater. Seperti beberapa karya dari Rachman Sabur, produksi Teater Payung Hitam Bandung, Karya Putu Jaya, dan karya Artur S. Nalan.

\section{DAFTAR RUJUKAN}

Ahimsa-Putra, Heddy Shri. (2001), Strukturalisme Lévi-Strauss Mitos dan Karya Sastra, Galang Press, Yogyakarta.

Anirun, Suyatna. (2002), Menjadi Sutradara, STSI Press Bandung. Studiklub Teater Bandung bekejasama dengan PUSLITMAS STSI Bandung

Brockett, Oscar. (1999). History of the Theatre.London, Allyn and Bacon Comp.

Brockett, Oscar G. (1988), The Essential Theatre, Fourth Edition, Holt, Rinehart and Winston, Inc, USA.

Ching, Francis D. K. (2007), Architecture; Form, Space, and Order, New Jersey: John Wiley \& Sons, Inc.

Culler, Jonathan, (2003), Barthes, terj. Ruslani, Yogyakarta: Penerbit Jendela

Damono, Sapardi Djoko. (2012), Alih Wahana, Edisi Revisi Pertama 2012, Editum

Djelantik, A.A.M. (2002), Estetika Sebuah Pengantar, MSPI. Bekerjasama dengan kuBuku, Bandung.

Ekadjati, Edi S, (2014), Kebudayaan Sunda, Suatu Pendekatan Sejarah, PT Dunia Pustaka Jaya, Bandung.

Hays, K. Michael. (1998), Architecture Theory-Since 1968, Massachusetts, USA: Colombia Book of Architecture.

Holt, Claire. (2000), Melacak Jejak Perkembangan Seni Di Indonesia. Bandung: arti.line.

Husein, Fathul A. (2017), Teater Payung Hitam Dan Transgresi Kuasa Tubuh, dalam Kumpulan Makalah Diskusi “Tubuh Teater Tubuh" Peringatan 34 Tahun Teater Payung Hitam, Bandung. 
Hutcheon, Linda. (2006), A Theory of Adaptation, London and New York: Routledge Taylor\& Francis Group.

Isser, Wolfgang, (1978), The Act of Reading; A Theory of Aesthetic Response, London: The Johns Hopkins University Press.

Kernoddle George.R. (1967). Invitation of the Theatre, Harcourt, Brace \& World, Inc, USA.

K.M, Saini. (2002), Kaleidoskop Teater Indonesia. STSI Press Bandung, Lembaga Penerbitan PUSLITMAS STSI Bandung.

. (2000), "Teater Indonesia, Sebuah Perjalanan dalam Multikulturalisme". Dalam Nur Sahid (ed.). Interkulturalisme dalam Teater. Yogyakata: Yayasan Untuk Indonesia (YUI).

. (1988), Teater Indonesia dan Beberapa Masalahnya. Bandung: Bina Cipta.

Land, George, (1973), Grow or Die; The Unifying Principle of Transformation, New York, USA: Random House.

Mitter, Shomit. (2002), Stanislavsky, Brecht, Grotowski, Brooks. Sistim Pelatihan Lakon, Terjemahan; Yudiaryani, Diterbitkan atas Kerjasama MSPI dan arti, Yogyakarta.

Murgiyanto, Sal. (2016), Pertunjukan Budaya dan Akal Sehat, Fakultas Seni Pertunjukan-Institut Kesenian Jakarta (IKJ), Kerjasama dengan SENREPITA, Yogyakarta.

Nalan, Arthur S. (1998), Mencipta Teater, Sebuah Pengantar Memahami Teater dan Antalogi Naskah Lakon, CV. Geger Sunten, Bandung.

Nalan, Arthur S. (2006), Teater Egaliter. Bandung. Sunan Ambu Press.

Pavis, Patrice. (1992), Theatre at the Crossroads of Culture, London: Routledge.

Rosidi, Ajip. (1966), Kesusastraan Sunda Dewasa Ini, Jatiwangi: Cupumanik.

Rusmana, Tatang. (2011), Makrokosmos Parahiangan dalam Drama Kidung Jakabandung dalam Narasi Metaforik, Strategi, dan Elanvital, Jurnal Ilmiah Seni \& Budaya, Panggung, Vol.21 No.3, STSI Bandung.
Sabur, Rachman. (2017), Reportase Tubuh, dalam Kumpulan Makalah Diskusi "Tubuh Teater Tubuh" Peringatan 34 Tahun Teater Payung Hitam, Bandung.

Schechner, Richard. (2004), Performace Theory, London dan New York: Routledge.

(2002), Performace Studies: an Introduction, London: Routledge.

(1994), Environmental Theatre An Expanded New Edition including "Six Axioms For Environmental Theatre", Applause, New York, London.

Sumardjo, Jakob. (2015), Sunda Pola Rasionalitas Budaya, Kelir, Bandung. (2014), Estetika Paradoks, Kelir,

Bandung.

(2013), Simbol-Simbol Mitos

Pantun Sunda, Kelir, Bandung. (2003), Simbol-Simbol Artefak Budaya Sunda, STSI Press, Bandung.

Suyono, Seno Joko, (2015), Tradisi dan Mitologi Kita: Dari Schechner sampai Julie Taymor, dalam Pendidikan, Birokrasi Seni dan Pergulatan Teater Timur \& Barat, 80 Tahun A Kasim Achmad, Pentas Grafika: Jakarta.

Wijaya, Putu. (2004), "Teater Tanpa Lakon", dalam Teater Payung Hitam, Persepektif Teater Modern Indonesia, Kelir, Bandung.

Yohanes, Benny. (2013), Teater Piktografik, Migrasi Estetik Putu Wijaya dan Metabahasa Layar, Cipta, Dewan Kesenian Jakarta.

Yudiaryani. (2015), WS Rendra dan Teater Mini Kata, Galang Pustaka, bekerja sama dengan Istitut Seni Indonesia (ISI) Yogyakarta.Yogyakarta.

. (2012), Membaca Pendidikan Seni dan Budaya Melalui Pergeseran Paradigma Seni Pertunjukan Teater. Pidato Ilmiah dalam rangka Dies Natalis ISI Yogyakarta ke XXVIII. 30 Mei 2012.

. (2002), Panggung Teater Dunia. Yogyakarta. Pustaka Gondho Suli.

Yunus, Umar, (1985), Resepsi Sastra: Sebuah Pengantar, Jakarta: PT Gramedia. 